\title{
State Preemption of Local Laws: Origins and Modern Trends*
}

\author{
Christopher B. Goodman ${ }^{\dagger} \quad$ Northern Illinois University \\ Megan E. Hatch Cleveland State University \\ Bruce D. McDonald, III North Carolina State University
}

\begin{abstract}
American cities are creatures of their states, with states both granting and limiting the power of their cities. This relationship is characterized by how cooperative or competitive states are with cities in their legislation. Despite the recent attention given to state preemption of local laws, this is not a new phenomenon. Part of the confusion surrounding preemption is that there is no shared definition or understanding of its forms. The purpose of this article is to begin to create that shared conception. In doing so, we define preemption according to its historic origins as the use of coercive methods to substitute state priorities for local policymaking. We argue modern state preemption of local laws can be divided into four phases, each with their own policies and mechanisms. We show how preemption has changed over time, shifting the functional, legal, and political relationship between states and their cities. Together, these phases help assist policymakers and administrators in understanding the nature of state preemption, and thus how to create and implement local policies in an environment where the distribution of power between governments is competitive and changing.
\end{abstract}

Keywords: Preemption, Local government autonomy, Intergovernmental relations

\section{Introduction}

American cities are creatures of their states, with states both granting and limiting the power of their cities. Bowman $(2017,2)$ argues the nature of the relationship between states and their cities is fundamentally a question of the "relative distribution of power." However, Hicks et al. (2018) maintain this relationship is also characterized by how cooperative or competitive states are in their legislation. One illustration of this relationship that in recent years has increasingly become a topic of both public and academic discourse is state preemption of local legislation. For example, the North Carolina "Bathroom Bill" (H.B. 2) limited cities' rights to pass antidiscrimination laws (among others). This led to national press coverage and boycotts that cost the state more than \$395 million (Ellis 2016).

Despite the recent attention given to state preemption of local laws, this is not a new phenomenon. In the latter half of the nineteenth century, it was common practice for state legislatures to pass so-called "ripper" legislation that removed service delivery responsibilities from cities without their input or consultation (Zimmerman 2012). In many ways, this led to the modern home rule movement, even if the role of cities in the broader intergovernmental system has always been at the whim of state policymakers, with states taking steps to ensure the behavior of

${ }^{*}$ Accepted for publication at Perspectives on Public Management E Governance.

${ }^{\dagger}$ August 28, 2020 
local governments falls in line with state preferences. However, preemption is about more than whether a state has home rule or Dillon's Rule. Even defining what institution preempts is unclear, as some studies focus on legislative preemption (Riverstone-Newell 2017), while others examine court-driven preemption (Swanson and Barrilleaux 2018). Part of the confusion surrounding preemption is there is little shared definition or understanding of its forms. The purpose of this article is to begin to create that shared conception. In doing so, we define preemption according to its historic origins as the use of coercive methods to substitute state priorities for local policymaking.

We argue modern state preemption of local laws can be divided into four epochs, each with its own policies and mechanisms. We show how preemption has changed over time, shifting the functional, legal, and political relationship between states and their cities. Together, these epochs help policymakers and administrators understand the nature of state preemption of local laws. We begin with the modern era of preemption typified by the tax revolts and tax and expenditure limitations (TELs) of the 1970s and 1980s. The second epoch is the era of unfunded mandates that alter the spending priorities of local governments that were popular in the late 1980s and early 1990s. The third epoch largely deals with public health issues and occurred in the late 1990s and early 2000s. Finally, we examine the fourth and current epoch of state preemption, which is less typified by the policy areas preempted and more by the level of policy restrictiveness and punitiveness.

The recent uptick in research on state preemption of local ordinances (see, for example, Crosbie, Schillinger, and Schmidt 2019; Diller 2020; Flavin and Shufeldt 2019; Fowler and Witt 2019; Swanson and Barrilleaux 2018) suggests this is a growing and important area of interest among scholars of intergovernmental affairs as well as state and local governments. What is missing from the literature is a comprehensive understanding of the nature of state preemption. We intend for this analysis to chart the history of state preemption of local ordinances, identify how local governments have reacted to these changes, and determine what changes if any have occurred in local governments. In doing so, we plot a research agenda focused on how to evaluate the impact of state preemption on local government managers and on local government systems more broadly. There are limitations to this approach. The phenomena we discuss is U.S.-based; however, we believe the conceptual issues we raise have implications for any federal system. Additionally, our historical approach offers no empirical analysis. We draw upon broad trends with the aim of informing future empirical analysis.

We begin by examining the history of state-local relations in the United States with a focus on state policymaking related to local governments. Next, we define preemption in the state context and explore its various forms. We then move on to an analysis of the four epochs of preemption (i.e., TELs, unfunded mandates, public health, and the new preemption). Finally, we close with a discussion of the potential problems preemption poses for local government managers and chart a future research agenda for how to examine preemption in light of our analysis.

\section{Background}

\section{State-Local Relations in the United States}

Local governments in the United States are constructs of their respective states. States decide the relative level of autonomy of different forms of local government. This relationship between state and local governments has been recognized by federal and state courts since Judge John Dillon's 1868 court ruling in City of Clinton v. Cedar Rapids $\mathcal{E}$ Missouri River Railroad. In a series of 
court cases, Dillon lays out a doctrine of complete subservience of municipal corporations to state legislatures. As (Bowman and Kearney 2014,3) explain, the strictest interpretation of Dillon's Rule means that "any doubt regarding the legality of a specific local government power is resolved in favor of the state." Currently, thirty-nine states have adopted Dillon's Rule (Richardson 2011). In thirty-one of those states, Dillon's Rule applies to all local governments, while in the remaining eight states it applies only to specific jurisdictions.

Even in Dillon's Rule states, some state legislatures have granted local governments home rule powers that allow local areas to tailor their public policies to meet local needs without consultation with the state legislature (Briffault 1990). As Richardson (2011) explains, home rule fundamentally has two components. First, it implies that local governments are in charge of purely "local" affairs and second, that local governments should be free from interference from state actors. ${ }^{1}$ For a time, concurrent with Judge Dillon's ruling, these two components were part of a legal movement to cede the powers of self-government to local government, largely free from interference from the state. Known as the Cooley Doctrine, this approach to local government autonomy faded as a legal doctrine once Dillon's Rule was upheld by the U.S. Supreme Court in 1903 (Richardson 2011). Nonetheless, states have continued to grant limited home rule powers to their local governments (McDonald III and Gabrini 2014). In doing so, states have not completely given up their oversight powers, but rather have decided that some areas of oversight are less important than others. Currently, forty-eight states grant some or all local governments home rule powers; however, the amount of powers and local government's ability to access them vary highly by state.

There is a rich literature attempting to determine the exact nature of local autonomy among the states. Given the legal and political ambiguity of home rule powers, this is no small feat. In general, it is thought that local governments have been losing power and authority to states for the last forty years. Stephens (1974) outlines and Bowman and Kearney (2011) update a measure of state centralization composed of three dimensions: fiscal responsibility, service delivery, and public personnel. Each dimension measures the balance between state responsibility and local government responsibility. The trend from 1957 until 2008 was toward increasing centralization among the three dimensions with interstate variation. ${ }^{2}$ Some states have become considerably more centralized, while others have become more decentralized (Bowman 2017). Perceptual measures of centralization also point to a loss of local autonomy (Bowman and Kearney 2012).

Given Dillon's Rule, the granting of limited home rule powers, and changes in state centralization over time, local governments are at a disadvantage relative to the state in matters of local policymaking. This relationship necessarily leads to conflict between local governments and the state. The changing political landscape at the state level (trending more conservative) and the local level (trending more liberal) amplifies this conflict as the two sides see each other as political adversaries (Einstein and Glick 2017), constituting a marked departure from previous time periods when local government exerted significant lobbying pressure on state legislatures (Berman 2003).

1. It is important to note that the home rule movement and the council-manager form of municipal government are inextricably linked. The ability to control municipal form locally led to the adoption of city managers through alterations of municipal charters (see Dodds (1924) for a contemporaneous outline). These two issues were set pieces for Frank Goodnow's advocacy for a politics-administration dichotomy (1900), later incorporated into White's (1926) textbook. See Guy (2003) for a more in-depth examination analysis of early development of public administration as a separate field.

2. The research concerning state centralization has not been updated since this time; however, it appears the trend continues to this day. 
It is within this complicated context that state legislatures decide to pass legislation preempting their cities.

\section{The Role of State Legislatures}

As local governments are constructs of the state, state legislatures play a large role in determining how local governance will be arranged. Historically, state legislatures have spent a significant amount of time considering issues of local affairs (Burns and Gamm 1997). Between 1871 and 1921, state legislatures in Alabama, Massachusetts, and Michigan had numerous committees related to local affairs and between 25 to 50 percent of legislation pertained to local issues. Burns et al. $(2009,61)$ note the prominence of legislation related to local affairs continues in state legislatures and the importance of such legislation cannot be overstated, going as far as contending "local policy outcomes often occur in the state legislature." They further assert that unity among the urban delegation with respect to "big city" bills limits conflict about such bills and allows the urban delegation to manage the legislative process effectively. The effects of disunity among the urban delegation can spell disaster for local legislation (Gamm and Kousser 2013), particularly when larger urban delegations break along party lines. As Gamm and Kousser (2013) explain, this process only gets worse the larger the urban delegation is. However, legislators with prior local government experience are more attentive to local issues in the state legislature and this previous service can potentially moderate any disunity effects (Lovrich and Newman 2004).

Bowman and Kearney (2014) describe the more recent (2011-2012 biennium) treatment of local governments in state legislatures. They find nearly 2,500 new laws pertaining to general purpose local governments (excluding school districts and special districts) with high variance among states. These laws are classified as empowering or restricting so as to give an average of state-specific legislation related to local governments. During the 2011-2012 biennium, thirty-three states empowered local governments, twelve restricted them, while in five states empowering and restricting legislation canceled each other out. Bowman (2017) observes the legal status of local governments (Dillon's Rule or home rule) is not influential in the passage of empowering or restricting legislation. In general, the prevalence of local legislation in state legislatures declined over the twentieth century; however, local bills still made up 20 percent of all legislation in 2000 (Gamm and Kousser 2010). While legislatures have put local affairs on the back burner, they are still active in the management of local government affairs.

\section{Preemption of City Ordinances}

What is clear from the preceding discussion is that state legislatures are in control of local governments' destinies and have been increasingly willing to move powers away from local governments. At the same time, residents strongly support empowering local governments to solve local problems (Schneider, Jacoby, and Lewis 2011). Among those scholars who study local autonomy, the general consensus is, absent a compelling reason for state centralization, ${ }^{3}$ "[1]ocal decisions are best made by locals" Hooghe and Marks $(2009,232)$ because local governments solve local problems with local ideas (Frug and Barron 2008). Unsurprisingly, municipal officials also feel the local level is the best place for policy decisions to be made (DuPuis et al. 2018).

As Frug and Barron (2008) note, the current legal structure in most states affords local governments too little flexibility to effectively solve local problems. At the same time, state legislatures

3. Examples include eliminating spillovers, issues of fiscal equivalence, or incompetent and/or corrupt local officials. 
do not debate local issues in a serious or nuanced manner, thus leaving local governments in a bind. Local governments can push forward with dubious legal authority or leave local voters' demands unfulfilled. In more recent years, local governments have turned to the former by adopting policies with dubious legal authority to do so.

When a local government wanders into policy territory a state believes is inappropriate, the state is faced with a choice of what to do. If a state deems a local government to have stepped outside of its current legal authority as clearly defined in law, the state may use the courts to enforce current rules (Swanson and Barrilleaux 2018). This method of preemption, namely, court-driven preemption, requires a local ordinance to be adopted to begin the process. A plaintiff may view a local ordinance as unfair and sue to stop its enforcement; however, the courts may find such laws to be consistent with current state law. Therefore, this method does not guarantee preemption. A second mechanism is driven by the executive branch. Most recently, this has occurred when Governors used their Emergency Powers to issue Executive Orders preempting their cities from responding to the COVID-19 pandemic (McDonald III, Goodman, and Hatch 2020). A third mechanism is legislatively-driven preemption. Although this method of preemption requires no specific action be taken by a local government, legislative preemption is often spurred by the passage or threat of passage of a particular local ordinance (Boswell 2018). Under this method of preemption, a state legislature alters the rules of the game for local governments, thereby reducing their legal authority to enact local ordinances in a particular area. A fourth preemption mechanism is referendum preemptions (Boswell 2018). These referenda may begin with the legislature but require public approval before they are enacted. In this paper, we primarily focus on the latter two mechanisms.

As explained by Briffault (2018) and Wagner et al. (2019), regardless of the means of preemption, there are various styles of state preemption that influence the range of potential actions that can be taken by local governments. Wagner et al. (2019) classifies these into four different types: vacuum, ceiling, floor, and punitive preemptions. Vacuum preemptions occur when the state preempts local action without setting a statewide standard for this policy area. This style of preemption leaves a policy/regulatory vacuum where cities are prevented from regulating an activity that the state has chosen not to regulate. The aim is not to determine which entity should regulate, but rather to deny regulation entirely (Briffault 2018). Ceiling preemption is when the state prevents local governments from exceeding a state-imposed policy/regulation. The prototypical example of a ceiling preemption is state minimum wage laws that often include provisions whereby localities cannot exceed the state imposed minimum wage. This style of preemption precludes any attempt to tailor local policy to local circumstances and is generally justified by state governments as eliminating regulatory hurdles for business. Rather than contending with a myriad of local regulations, the state imposes uniformity on the process.

Floor preemptions are the near opposite of ceiling preemption. Rather than prohibiting any policy/regulatory action above a state minimum, floor preemption sets the statewide minimum as the baseline and localities are free to set their own higher levels. This is a preemption in so much as a locality is not free to set a policy/regulation lower than the state minimum. Finally, punitive preemption is not necessarily an independent preemption style, but rather a feature of newer preemption laws. Punitive preemptions attempt to hold local officials criminally or civilly liable for being out of compliance with state law. Punishment can include fine or removal from office for local elected officials or the denial of state aid to the local government (Briffault 2018; Wagner et al. 2019). This type of preemption law is sometimes referred to as super-preemption 
(Riverstone-Newell 2017) or hyper-preemption (Scharff 2018). Punitive preemptions are unique among the types as they also operate either by a preemption being imposed or the threat of a preemption (Diller 2020).

In addition to the form and type of preemption, these state actions also vary in their scope. Preemptions may be very broad, such as Arizona's 2016 law preempting local governments from passing legislation that contradicts state law, as defined by Arizona's Attorney General (Sanchez and Rau 2016). State preemptions may also be quite specific and targeted, such as bans on local governments' regulation of plastic bags in Arizona, Idaho, Michigan, Missouri, and Wisconsin (DuPuis et al. 2018).

In summary, the relationship between state governments and their cities is complex and changing. States are now less likely to take up local issues, yet still choose to restrict local policymaking through preemption, in which they substitute state priorities for existing or potential local priorities. This preemption can take several different forms. The next section examines four epochs of preemption (i.e., TELs, unfunded mandates, public health, new) to identify similarities and differences in the styles of preemption enacted, the impact on local governments, and the responses of those governments to preemption.

\section{The Four Preemption Epochs}

\section{The 1970s and 1980s: Tax and Expenditure Limitations}

One of the first forms of preemption to be used by states was tax and expenditure limitations (TELs) (Stallmann et al. 2017). As a type of fiscal policy, TELs aim to curb or restrict the budget process of a government in order to limit the ability of the government to grow (Martell and Teske 2007). As the name points out, the constraint on growth is achieved by placing a restriction on a government's tax revenue or spending. The mechanism by which a TEL is imposed, however, varies considerably. The most common approach is tying the growth of expenditures to the growth of the local economy, typically measured as personal income, or tying the limitation to a specific level, such as a fixed share of the local economy or a predefined rate of increase (Stallmann et al. 2017).

Initially, TELs were adopted as a form of government protest in the early 1800s, though they began to emerge in earnest during the tax revolt of the 1970s and 1980s with the adoption of property tax limits, such as California's Proposition 13 and Massachusetts' Proposition 2 1/2 (Atchison 1992; Deller, Stallmann, and Amiel 2012; Sun 2014). The string of recessions between 1969 and 1982, combined with the fact that tax codes were not indexed for inflation, left many households struggling financially (Domitrovic 2014). The movement of TELs by states can thus be seen as a means of limiting the ability of local governments to impose a financial hardship on their constituencies. However, in an era of conservatism, it can also be viewed in the light of limiting the social programming local governments provided. By limiting the tax revenues available or restricting the ability to spend, local governments were forced to choose between providing core public services and other public goods and services that met the social needs of the community. The TELs that emerged in the tax revolt of the 1970s and 1980s were just as focused on the state limiting the capacity of local governments to provide social programs as they were on controlling the growth and expansion of the effected governments (Park, Maher, and Ebdon 2018; Stallmann et al. 2017). 
The TEL movement to restrict the authority of local governments has typically been presented as a grassroots or public choice initiative; however, their origins are more closely linked to statelevel action (Stallmann et al. 2012). Often emerging from a small group of state reformers (either legislators or citizens), ${ }^{4}$ the statutory and constitutional provisions that comprised the TELs were usually broad in their scope and applied to nearly all local governments within the state. The limitations left little discretion to the local governments in their applications, thus placing a significant limit on local choice (Martell and Teske 2007). Stallmann et al. (2017) report the impact of the TELs imposed by states has altered the relationship between local governments and their constituencies, while also significantly altering their capacity to provide public goods and services.

The imposition of TELs by states forced local governments to innovate, and the most common form of innovation was the establishment of special districts (Bowler and Donovan 2004). Like municipalities and counties, special districts are legal creations of the state that come with an established set of powers (Foster 1997), including the power to tax, charge fees, issue debt, and appropriate land (Burns 1994). Most importantly, special districts also come with the capacity to provide public goods and services similar to those that may be provided by a municipality. While the TELs imposed by states to preempt local government action or expansion included both cities and counties in the provisions, they often omitted special districts (Bowen 1984; Gerber et al. 2001). As states sought to preempt local government action in the 1970s and 1980s, local governments began to turn to special districts as a means of escaping the preemption traps established by states. By creating special districts, local governments could shift the burden of some services from their own shoulders while also controlling the behavior of the district (Bowler and Donovan 2004; Carr and Farmer 2011). This burden shifting can be seen in the data, with the Census of Government reporting a fairly stable number of municipalities but a 210 percent increase in the number of special districts between 1952 and 2012 (Goodman and Leland 2019). The majority of these new districts centered on providing social programs, such as housing and community development, libraries, and public health.

\section{The 1980s and Early 1990s: Unfunded Mandates}

Although unfunded mandates do not necessarily fit into the definition of preemption as we have currently laid out, they do have many features of preemption that makes examining the local reaction to state-imposed unfunded mandates warranted. The issue of state-imposed unfunded mandates is not new. As Zimmerman (2012) explains, Goodnow (1895) complained about state legislative mandates on local governments; however, the issue of state (and federally) imposed mandates on local governments reached a head in the 1980s and early 1990s, as the federal government attempted to deal with fiscal stress by devolving many programs to the state level, with states in turn mandating local action (Advisory Commission on Intergovernmental Relations 1990; Berman 2003). While not exactly preemption, state-imposed unfunded mandates have features of preemption. Specifically, "mandates distort local priorities, restrict managerial flexibility, and impose costs that have to be paid though local revenues" (Berman 2003, 78). In essence, an unfunded mandate substitutes the state legislature's policy priorities for the local government's policy pri-

4. It is important to note that while the effect of TEL preemption is similar across preemptions, the means of preemption varies considerably. Not all are imposed legislatively. A number, particularly early standout examples like California Proposition 13 or Massachusetts Proposition 2 1/2, were imposed through state ballot or initiative processes. 
orities. This occurs in a similar manner to preemption, but rather than restricting the ability of a local government to make a policy choice, the legislature has mandated an action. ${ }^{5}$

Evidence of the number of unfunded mandates imposed on local governments in the United States is sparse. Local elected officials in Minnesota identified 150 "objectionable" rules and laws they would consider unfunded mandates (Nobles and Brooks 2000). In the 1980s, the state of Florida outlined 362 unfunded mandates imposed on cities and counties (Florida Advisory Council on Intergovernmental Relations 1991; Benton 2002). Over a similar time period, one in twelve new laws in Ohio imposed an unfunded mandate on local governments and that number was closer to one in four in Tennessee (Benton 2002). Although this is anecdotal evidence, stateimposed unfunded mandates were of particular concern in the 1980s and early 1990s.

Generally, local governments have little legal recourse against unfunded mandates. Home rule may provide some limited resources; however, the courts have been more inclined to side with state legislatures than local governments in the realm of mandates (Berman 2003). In a number of states, another response by local governments to the increase in unfunded mandates was to lobby the state legislature to impose constitutional or statutory requirements to reimburse local governments for the cost of such mandates (Berman 2003). As of 2012, fifteen states had amended their constitutions to limit unfunded mandates by 1) prohibiting them altogether without the acquiescence of the affected local government, 2) requiring reimbursement of some or all costs, 3) delaying the imposition of such mandates, 4) allowing local governments to ignore such mandates, 5) requiring supermajorities in the legislature to impose unfunded mandates, or 6) allowing governors to suspend such mandates (Zimmerman 2012). With some overlap, sixteen states have enacted similar limitations on unfunded mandates by statute.

An examination of one such limitation, Florida's constitutional Amendment 3 in 1990, suggests the constitutional limitations on unfunded mandates restricted the use of such mandates and expanded the role of the state in service provision relative to a synthetic Florida that never adopted Amendment 3 (Ross 2018). Prior research suggested Amendment 3 was successful in passage because voters were convinced that without it, taxes would rise and local priorities would be supplanted by state ones (MacManus 1991). Overall, Zimmerman (2012) asserts constitutional limitations on unfunded mandates are more effective at actually constraining state behavior relative to statutory limits that are easier to circumvent. Overall, local governments had little legal success at limiting the impact of unfunded mandates but saw more success at passing legislation and/or referenda to blunt the impact.

\section{The 1990s and Early 2000s: Public Health}

The third epoch of state preemptions relates to policies affecting public health, such as tobacco use and advertising, food labeling and nutrition, and firearm safety. These preemptions were predominately from the 1990s and early 2000s, although some authors cite them as going back as far as the 1980s (Pomeranz and Pertschuk 2017). For example, the pace of tobacco regulation preemptions peaked in the mid-1990s and plateaued after 1996, until repeals of the preemptions started in 2002

5. Some unfunded mandates do not work exactly in this manner. Rather, state and local priorities could align, and the state takes a leadership role in mandating a level of service provision. However, we contend that this is still consistent with our definition of preemption, the use of coercive means to substitute state policymaking of local policymaking. The lack of a choice about the service provision and the required revenue to pay for such service provision is preemptive. Thank you to an anonymous reviewer for pointing this out. 
(Mowery et al. 2012). Firearm safety preemptions were a very common form of preemption, with forty-three states having some form of gun preemption (Pomeranz and Pertschuk 2017).

Many of the public health preemptions limited the extent to which cities could regulate healthrelated industries. According to Pertschuk et al. $(2013,213)$, "[i]n public health, the term 'preemption' typically refers to 'ceiling' preemption, by which a higher level of government takes away the power of lower jurisdictions to adopt stronger laws." For example, preemptions banned cities from being stricter than their states in restricting smoking (Babb, Tynan, and MacNeil 2010). This is contrary to the advice of public health experts. Indeed, the Institute of Medicine recommends that states set minimum standards (Pomeranz and Pertschuk 2019), allowing cities to set stricter standards if they so choose.

The most common explanation for whether states decided to preempt public health policies during this epoch was the influence of powerful interest groups. In particular, the tobacco lobby was especially instrumental in getting states to adopt preemptions of tobacco regulation and clean air bills (Givel and Glantz 2001; Siegel et al. 1997). Monadari and Glantz (1998) find larger tobacco industry campaign contributions are associated with legislators acting in ways that are more favorable to the tobacco industry, including introducing and voting for tobacco regulation preemptions. This pattern of interest group influence existed across a variety of public health areas (Pertschuk et al. 2013), including the firearms and alcohol industries (Gorovitz, Mosher, and Pertschuk 1998). In Pomeranz and Pertschuk's (2017) study of legislative testimony, multinational corporations and an ALEC model bill backed Kansas' preemption of food, nutrition, and agricultural policy.

Interest groups such as the tobacco industry were effective at getting states to preempt policies unfavorable to their interests because of economies of scale. While public health organizations are more effective at the local level (Givel and Glantz 2001), larger industries cannot lobby every local government (Gorovitz, Mosher, and Pertschuk 1998). Instead, when these industries "pool their resources in trade associations or other collective bodies, [they] can afford to protect their interests at the state level, through state or regional offices" (37). Industry interest groups, therefore, were able to pass preemptions of policies, whereas public health groups were more influential at the local level. For example, local interest groups were able to partner with schools, businesses, and a city to institute social norm changes that led to tobacco policy changes, even in a state such as Oklahoma which preempted tobacco laws (Douglas et al. 2015).

Public health officials worry about the negative impacts of preemption on public health, particularly when the preemption bills include penalties for local governments that choose to ignore the preemption (i.e. punitive preemption) (Pomeranz and Pertschuk 2017). For example, in states where there was a preemption law for tobacco, there were fewer conversations about smokefree environments, thus hindering the change of social norms surrounding smoking (Mowery et al. 2012). In a survey of health officials in cities of 150,000 people or more, Rutkow et al. (2019) find 72 percent of health officials and 60 percent of mayors delayed or abandoned policymaking due to state preemptions. Over 90 percent of both groups said preemption was an obstacle to local policymaking. However, approximately 60 percent of respondents said they attempted to counter future preemption, mostly commonly by working with advocacy organizations and the state legislature.

When given the opportunity, cities acted quickly to counteract preemptions. For example, North Carolina's tobacco preemption bill included a three-month rollout period whereby any existing tobacco control laws would be allowed. More than half of the counties in the state proposed 
a tobacco regulation during that period and the number of local smoking regulations went from sixteen to 105 (Conlisk et al. 1995).

Towards the end of this epoch, public health preemptions decreased over time. Babb, Tynan, and MacNeil (2010) observed that between December 31, 2004 and December 31, 2009, seven states (declining from nineteen to twelve) no longer preempted laws banning smoking in government work sites, private-sector work sites, and/or restaurants. However, public health advocates still worried about the negative consequences of these preemptions.

\section{The 2000s to Today: "The New Preemption"}

The usage of state preemption of local ordinances seems to be accelerating in the current time period (DuPuis et al. 2018). Unlike the previous epochs, there does not appear to be a discernible pattern to the policy areas preempted (Briffault 2018). Rather, these new preemptions seem to be preventing local regulation in general without any concurrent state regulation (i.e. vacuum preemption). Riverstone-Newell (2017) suggests this is a response to a burgeoning amount of local policy innovation aimed at filling a void left by inaction on the part of state and federal policymakers. Local action has drawn the ire of state policymakers and they have responded by limiting local policymaking authority in increasingly punitive ways.

Some of the new preemptions contain provisions that go beyond the traditional intent of preemption (Scharff 2018). These punitive preemptions contain terms that all but require absolute compliance or face harsh penalties. These penalties, imposed on elected officials, administrators, or both, can include removal from office, fines levied against a person, or imprisonment (Scharff 2018; Swindell, Svara, and Stenberg 2018). Additional sanctions may also be imposed on noncompliant local governments (Briffault 2018); however, some states have entertained the idea of eliminating the ability of local governments to impose municipal regulations of any kind. Briffault (2018) refers to these as nuclear preemptions and argues that, if passed, they would redefine local self-governance in the United States. Scharff (2018) defines these somewhat differently explaining narrow punitive preemption is focused on particular actors (elected officials or managers), broad punitive preemption is focused on non-complaint local governments generally, and blanket preemption is similar to Briffault's explanation of nuclear preemption. Taken together, the new preemption is typified by a vacuum aimed at reducing local government regulatory powers and, in some circumstances, adding punitive elements to all but ensure compliance.

Not all new preemptions are punitive, but nearly all punitive preemptions are in the new era. As mentioned above, the new preemption epoch is typified by a broad range of policy areas preempted. These include (but are not limited to) limitations on local firearms regulations, workplace regulations, public health regulations, plastic bag bans, anti-discrimination regulations, sanctuary cities, and adoption of municipal broadband internet services (Briffault 2018). Many of these are vacuum preemptionspreventing local regulation while not providing any state guidance. As Riverstone-Newell (2014) mentions, the careers of local officials are dependent upon their ability to satisfy constituent demands. The wide-ranging nature of the new preemptions suggests a strategy to stifle a large amount of local policy making authority. In turn, this prevents the officials from satisfying constituents.

Both Briffault (2018) and Scharff (2018) outline a number of preemptions that fall into the category of punitive preemptions. Arizona's S.B. 1487 appears to be the most extreme version of punitive preemption. Under S.B. 1487, the Arizona attorney general had broad powers to investigate whether any local governments are out of compliance with Arizona state law and punish 
non-compliant local governments [seeBriffault (2018) and Scharff (2018) for a detailed legal explanation of the process]. As Scharff (2018) mentions, it appears this process is designed to stifle any local policy action in areas that are current preempted or might be preempted in the future. ${ }^{6}$ Though S.B. 1487 is the most extreme of the punitive preemptions, it combines the two approaches that are common in this era, vacuum preemption and punitive preemption.

The nature of these new preemptions has led to claims that these preemptions are more partisan than in the past. In particular, some scholars argue preemptions are responses by Republican controlled state governments to their more liberal, Democrat controlled cities (Flavin and Shufeldt 2019; Fowler and Witt 2019; Phillips 2017). However, other studies find the party in control is less important than the existence of an ideological difference between states and their cities (Barber and Dynes 2019). The historical approach utilized in this study provides some clarity on this issue as we find evidence of a pattern of political involvement in preemptions as form of preemptions evolve across each of the epochs. Until recently, longitudinal data on a variety of state preemptions has not been available, so the testing for a causal relationship between partisan and preemption could not be conducted. Early studies with this new data across some policy areas suggest ideology does influence the likelihood of a state adopting a new preemption (Goodman and Hatch 2020).

Given the often-punitive nature of the new preemption, local governments have limited options on how to respond. Recently, the National League of Cities (NLC) released a report suggesting a three-pronged response strategy (Wagner et al. 2019). This includes communicating the problem of preemption to local voters and state elected officials, forming coalitions to fight preemption, and using the court system when available. Swindell, Svara, and Stenberg (2018) suggests six potential routes to coping with preemption at the local level. The first is defiance of new preemptions. Given the features of the new preemption, this approach is not without risk. Potentially less risky is to rely heavily on existing or remaining legal authority and/or home rule powers to respond. Third is to attempt to use state referenda, where available, to directly change the law. Fourth and similar to the second is to devise circumvention methods that are consistent with existing law but allow action to continue. Fifth is to lobby the state legislature to expand the powers of local governments. The final recommendation is similar to the approach of NLC and raise awareness of the impacts of preemption in an effort to educate state policymakers about the repercussions of their actions. These two approaches suggest working within the potential punitive constraints of the new preemption may be the only real option available to many local governments.

\section{Toward a Comprehensive Understanding of Preemption}

The preceding sections outlined the four preemption epochs. An overview of the epochs and their details is provided in Table 1. The first modern preemptions, in the 1970s and 1980s, were TELs, which restricted local governments' tax revenue and/or spending. Local governments responded by innovating, often by establishing special districts. In the 1980s and early 1990s, state preemption more often took the form of unfunded mandates. The most common response by local governments was to lobby the state legislature to create requirements making it difficult to impose unfunded mandates or reimbursing the local governments their cost. The third epoch, in the 1990s

6. Under S.B. 1487, a local government can be considered non-compliant if they do not repeal local laws that are subsequently preempted. 
Table 1: Overview of Preemption Epochs

\begin{tabular}{|c|c|c|c|c|}
\hline Epochs & Years & $\begin{array}{l}\text { Type of } \\
\text { Preemption }\end{array}$ & Features & Example \\
\hline $\begin{array}{l}\text { Tax and } \\
\text { Expenditure } \\
\text { Limitations }\end{array}$ & 1970 s to 1980 s & Ceiling & $\begin{array}{l}\text { - Caps on local tax rates } \\
\text { - Caps on the increase in local } \\
\text { spending }\end{array}$ & $\begin{array}{l}\text { - CA Proposition } 13 \\
\text { - MA Proposition } 2 \\
1 / 2 \\
\text { - CO Taxpayer Bill of } \\
\text { Rights }\end{array}$ \\
\hline $\begin{array}{l}\text { Unfunded } \\
\text { Mandates }\end{array}$ & $\begin{array}{l}\text { 1980s to early } \\
1990 \text { s }\end{array}$ & Floor & $\begin{array}{l}\text { - State-mandated service pro- } \\
\text { vision, training, or other non- } \\
\text { optional governmental activ- } \\
\text { ity } \\
\text { - Usage of local revenue to im- } \\
\text { plement a state-mandate }\end{array}$ & $\begin{array}{l}\text { - GA Planning Act of } \\
1989 \\
\text { - IL } 65 \text { ILCS 5/11-20- } \\
16\end{array}$ \\
\hline Public Health & $\begin{array}{l}\text { 1990s to early } \\
\text { 2000s }\end{array}$ & $\begin{array}{l}\text { Ceiling } \\
\text { Vacuum }\end{array}$ & $\begin{array}{l}\text { - Regulate public health } \\
\text { - Influence of powerful interest } \\
\text { groups }\end{array}$ & $\begin{array}{l}\text { - NC H.B. } 957 \\
\text { - TN CODE ANN. } \\
\text { \$39-17-1551 }\end{array}$ \\
\hline $\begin{array}{l}\text { The New } \\
\text { Preemption }\end{array}$ & 2000s to Today & $\begin{array}{l}\text { Vacuum } \\
\text { Punitive }\end{array}$ & $\begin{array}{l}\text { - Penalties for noncompliance } \\
\text { - Partisanship }\end{array}$ & $\begin{array}{l}\text { - AZ S.B. } 1487 \\
\text { - NC H.B. } 2\end{array}$ \\
\hline
\end{tabular}

and 2000s, saw a rise in preemptions of laws related to public health, limiting local governments' abilities to regulate health-related industries. Although many of these preemptions were eventually repealed, local governments also enacted legislation to counteract the preemptions when that option was available to them. Finally, the new preemption epoch began in the 2000s. These state actions are often vacuum preemptions that prevent local regulation and punitive preemptions that punish local governments who try to counteract the preemptions. Local governments are still struggling with how to respond to these preemptions, and working through existing mechanisms such as public involvement, referenda, and the courts appear to be the most promising responses.

Despite challenges to local government innovation and responsiveness, preemptions are not inherently normatively good or bad. There are examples of preemptions that have had serious negative consequences, such as preemption of tobacco regulation which harmed public health or North Carolina's H.B.2 "Bathroom Bill" which eventually cost the state hundreds of millions of dollars in lost revenue. However, other preemptions have had positive outcomes, such as New York's ban on hand-held phones while driving (Berman 2003) or Oregon's preemption of local zoning ordinances to encourage more and denser housing development (Grabar 2019). Given that state governments have the constitutional right to limit the actions of their local governments, it seems unlikely that states will stop preempting their local governments.

While the four epochs represent different types of preemption, each form represents challenges to local government innovation and the ability of sub-national jurisdictions to determine local solutions to local problems. In essence, many preemptions substitute local administrative expertise for state-level political preferences. This is an enduring debate in public administration what is the appropriate balance between bureaucratic expertise and political accountability? State preemptions solidly preference political accountability, leaving local government managers having to respond to both state and constituent pressures. 
The historical approach we utilize allows us to identify the ways in which state governments coercively substitute their priorities for existing or potential local agendas. This process is driven by states' political goals, such as preferences for specific funding mechanisms, responding to interest group pressure, or partisan preferences. Often, states preempt policy issues that are nationally salient and polarizing, such as smoke-free public spaces and plastic bag bans. This makes questions about the appropriateness of preemptions and local government responses inherently political questions about power and accountability. Such political controversies are inherent to intergovernmental relationships, such as that between states and their cities.

Indeed, preemptions are a continuation and escalation of patterns of intergovernmental relationships within a federalist system. Bowman and Kearney (2011) clearly outline the continued centralization of power at the state level and local officials perceive this centralization to be more extreme than state officials (Bowman and Kearney 2012). As our historical approach demonstrates, the types and kinds of preemption and their effects on local governments has changed over time. The trend of this change has been toward more restrictive preemptions, which, in turn, is at odds with public opinion about how local governments should respond to local issues (Schneider, Jacoby, and Lewis 2011). Carried forward to preemption, local governments are responding to demands made by their residents for action. The substitution of state priorities for local priorities upends this entirely.

Theoretically, state preemptions raise questions about efficiency and competition within states. If Tiebout (1956) is correct, states would ideally be comprised of a large number of local governments, each with their own bundle of services and taxes. This heterogeneity increases efficiency by allowing citizens to choose their preferred bundle. While there are critiques of this theory (Howell-Moroney 2008), state preemption would decrease efficiency by limiting the options available to local governments. These local governments would behave in increasingly similar ways, limiting their responsiveness to their citizens and decreasing competitiveness. Given the reality of state preemptions, it is essential for local government policymakers and managers to understand how to work within the new preemption regime while remaining responsive to their local constituents. As Sances (forthcoming) observes, local governments are responsive to public opinion when they are not constrained by state policies. More constraints may, therefore, decrease responsiveness.

However, state governments preempt their local governments at their own peril. Big cities are the economic drivers of their states, and if state preempt their cities, they are hindering cities' abilities to enact economic policy. This was apparent in several of the preemption epochs, with local governments having to innovate by creating special districts or lobbying their state governments in order to have the control over their budgets to achieve their policy priorities. While many of the blanket preemptions are still too recent for proper data collection and policy evaluation, future research should explore the extent to which these preemptions harmed the economy of the states' large cities, and therefore the overall economic health of those states.

For policymakers such as mayors and city council members, the challenge is how to implement policy responsive to their constituents' needs within a restrictive preemption environment. In general, local governments can either comply or fight back against state preemptions. Darcy and Holman $(2019,3)$ suggest local governments are rationally expressive, seeking "to signal commitment to local needs while avoiding costs associated with non-compliance." This action can take a number of forms. Working with state legislators is one approach these policymakers often takein essence attempting to change the rules of the game (Rutkow et al. 2019). In other cases, 
local policymakers sensitive to the requirements of preemptions are able to move quickly to pass legislation before the preemption goes into effect (Conlisk et al. 1995). A final approach has been to turn to the constituents themselves, through public relations campaigns or referenda, to put pressure on the state to repeal the preemption (Douglas et al. 2015; Swindell, Svara, and Stenberg 2018). While these three approaches have had some limited success, they may not be available to all local policymakers. Therefore, mayors and city council members will need to think about how to best create and implement local policies in an environment where the distribution of power between governments is competitive and changing. Organizations such as the National League of Cities, as well as within-state urban delegations, could be helpful in sharing information and best practices.

For local government managers, these big policy strategy questions play out in the day-to-day implementation of policies. Revenues still need to be raised, services still need to be provided. In order to achieve this, managers will need to be both proactive and reactive. Rather than just focusing on their local context, these managers need to consider the political environment their state. Local governments may have some power of self-governance (see McDonald III (2015) and (McDonald III and Gabrini 2014), but the political tides at play within a state can fluctuate the environment in which they operate, and their freedom within that environment (Kim, McDonald III, and Lee 2018). This dual role of acting politically while administering government services is not new. State preemptions highlight the false dichotomy between politics and administration (see Frederickson and Smith (2003)). In implementing policy, local government managers need

to be aware of what actions their state government restricts. This will be particularly challenging in the new epoch where preemptions frequently leave policy vacuums. Managers will have to adapt quickly to new policy challenges, such as short-term rentals, where states have prohibited regulation but questions about the proper role of government intervention remain. By examining the history of local governments' responses to preemption we discussed in previous sections, it seems clear that it will be up to managers and policymakers to innovate new ways to respond to the new policy environment, such as the development of special districts as a response to TELs in the 1970s and 1980s. We expect the need to innovate to be heightened in states where both the demand for local policy action and preemption activity are high. These local government officials will also need to act politically, both directly and indirectly through their constituents, to respond to and attempt to prevent future preemptions.

\section{Conclusion}

State preemptions of city ordinances are increasingly common in practice and academic study, yet little is known about the nature of these responses. We argue a barrier to knowledge and best practice generation has been a lack of a coherent definition and understanding of the history and nature of state preemptions. This paper contributes to the creation of this shared understanding by providing a common definition of preemption such that preemption is understood as the use of coercive methods to substitute state priorities for local policymaking. Using this definition as a guide, we then situate preemptions into four epochs. Within each of these epochs, the causes, form, and local government responses to preemption vary. Understanding the preemption form scholars are examining will help make sense of the varying conclusions reached by research about state preemption. Much of the current literature on state preemption of local laws considers all preemptions as derived from the same process by lumping them together (Flavin and Shufeldt 
2019; Fowler and Witt 2019; Swindell, Svara, and Stenberg 2018); however, the preceding analysis would suggest this is not an appropriate course of action due to the differences in the preemption epochs. That does not mean the epochs are mutually exclusive; there is overlap and transition between them. For example, hydraulic fracturing (fracking) preemptions have characteristics of both the third and fourth epochs. State bans on city regulation of fracking often leave policy vacuums (fourth epoch), but public health preemptions are often precipitated by lobbying from the oil and gas industry (third epoch) (Riverstone-Newell 2017).

Understanding the history of state preemptions moves scholars and practitioners closer to understanding the causes and consequences of preemptions. The historical approach to understanding preemptions that we utilize in this study allows for the determination of general patterns, categorized as the four epochs in our study, that might otherwise be missed when using statistical analysis to measure general trends. There is, however, still much to learn about the new relationship between states and their cities. We believe there are several big questions that future research should address. First, what does this changing relationship mean for local government managers? How can these administrators follow state law, avoid the penalties of preemptive preemptions, and still perform all the necessary local government functions? In particular, how do local managers address the policy vacuum left by some preemptions? For administrators, answering these questions will involve working at the boundary of politics and administration within a complex and changing policy environment. For example, states have recently preempted their cities' ability to respond to the COVID-19 pandemic (McDonald III, Goodman, and Hatch 2020) making these questions of local government responses both timely and complicated by the nature of the public health emergency that precipitated the preemptions.

Second, what impact does preemption have on state control of or responsibility for local governments? When states preempt their local governments they inject themselves into local affairs, but the legal implications behind this injection is unclear. It may be that preemption has minimal implications, but it may also shift the burden of responsibility for programs and services onto the shoulders of the state. Given the capacity of states to preempt and threaten to preempt, the degree that states impose on their local governments may vary, bringing differing legal implications along with it. From a theory building perspective, the answer to this question will need to address questions of public values and the appropriate balance of power between political and bureaucratic accountability.

Third, what policies are most likely to be preempted by what type of states? Answering this question will likely involve substantial data collection and organization, perhaps along the lines of Wagner et al.'s (2019) typology of preemption types. A useful methodological tool may be text analysis, which would allow researchers to identify common language and policy features (Garrett and Jansa 2015; Linder et al. 2018; Wilkerson, Smith, and Stramp 2015) in preemption legislation as well as city ordinances that triggered the preemption. Longitudinal and causal analysis are necessary to supplement existing cross-sectional conclusions. For example, while studies find a relationship between partisanship and preemption (Flavin and Shufeldt 2019; Fowler and Witt 2019), this needs to be confirmed with time series analyses across a variety of policy areas.

Fourth, in this article we only explore state preemptions of local ordinances. The federal government also preempts states and cities. For example, the issue of sanctuary cities is one that crosses all levels of government (Scharff 2018). Immigration is another policy area where states and the federal government both regulate local officials' behavior (Rosenbaum 2015). Further 
research is needed into the complex interplay between federal, state, and local priorities and coercion in the federalist system.

Last, clarity should be sought to establish when and how preemption should be used. While media accounts often point to preemptions with negative consequences for certain groups, as Frug and Barron (2008) point out, the decision of a state to preempt can have positive benefits. Given the possibility of a positive aspect, preemption should not be cast aside. Rather, a framework needs to be established that clarifies the use and nature of preemption and makes a normative argument for how it should be used. This is inherently a challenging question, one that involves complex statistical analysis, ethical considerations, and legal debates. In an era of preemption, however, it is, perhaps, the most important of the questions that we need to answer.

\section{References}

Advisory Commission on Intergovernmental Relations. 1990. Mandates: Cases in State-Local Relations. Washington, D.C.: Government Printing Office.

Atchison, Michael. 1992. "The Hancock Amendment, user fees, the plain meaning rule, and an invitation to challenge Buechner v. Bond." Missouri Law Review 57 (4): 1373-1389.

Babb, Stephen D., Michael A. Tynan, and Allison MacNeil. 2010. "State preemption of local smokefree laws in government work sites, private work sites, and restaurants - United States, 20052009." Morbidity and Mortality Weekly Report 59 (4): 105-108.

Barber, Michael, and Adam Dynes. 2019. “City-State Ideological Incongruence and Municipal Preemption." Last modified June 25, 2019.

Benton, J. Edwin. 2002. Counties as Service Delivery Agents: Changing Expectations and Roles. Westport, CT: Praeger.

Berman, David R. 2003. Local Government and the States: Autonomy, Politics, and Policy. Armonk, NY: M.E. Sharpe.

Boswell, Brad. 2018. "How State Legislative Preemption in Indiana Bars Local Governments from Building a Positive Economic Future." Indiana Law Review 51 (2): 471-497.

Bowen, Don L. 1984. "Reshaping special district government in Arizona." Arizona Review 32:1225.

Bowler, Shaun, and Todd Donovan. 2004. "Evolution in state governance structures: Unintended consequences of state tax and expenditure limitations." Political Research Quarterly 57 (2): 189196.

Bowman, Ann O’M. 2017. “The State-Local Government(s) Conundrum: Power and Design.” The Journal of Politics 79 (4): 1119-1129.

Bowman, Ann O’M, and Richard C. Kearney. 2011. "Second-Order Devolution: Data and Doubt." Publius: The Journal of Federalism 41 (4): 563-585.

. 2012. "Are U.S. Cities Losing Power and Authority? Perceptions of Local Government Actors." Urban Affairs Review 48 (4): 528-546. 
Bowman, Ann O'M, and Richard C. Kearney. 2014. "Transforming State-Local Relations." Paper presented at the annual conference of the American Society for Public Administration, Washington, DC, March 14-18.

Briffault, Richard. 1990. “Our Localism: Part I - The Structure of Local Government Law." Columbia Law Review 90 (1): 1-115.

—. 2018. “The Challenge of the New Preemption." Stanford Law Review 70 (6): 1995-2027.

Burns, Nancy, Laura Evans, Gerald Gamm, and Corrine McConnaughy. 2009. "Urban Politics in the State Arena." Studies in American Political Development 23 (1): 1-22.

Burns, Nancy, and Gerald Gamm. 1997. "Creatures of the State: State Politics and Local Government, 1971-1921." Urban Affairs Review 33 (1): 59-96.

Carr, Jered B., and Jayce Farmer. 2011. "Contingent Effects of Municipal and County TELs on Special District Usage in the United States." Publius: The Journal of Federalism 41 (4): 709-733.

Conlisk, Elizabeth, Michael Siegel, Eugene Lengerich, William MacKenzie, Sally Malek, and Michael Eriksen. 1995. "The Status of Local Smoking Regulations in North Carolina Following a State Preemption Bill." Journal of the American Medical Association 273 (10): 805-807.

Crosbie, Eric, Dean Schillinger, and Laura A. Schmidt. 2019. "State Preemption to Prevent Local Taxation of Sugar-Sweetened Beverages." JAMA Internal Medicine 179 (3): 291-292.

Darcy, Geoff, and Mirya Holman. 2019. “They're Coming for Your Gun Laws: State Preemption and Local Compliance in Firearms Policy." Working paper.

Deller, Steven C., Judth I. Stallmann, and Lindsay Amiel. 2012. "The impact of state and local tax and expenditure limitations on state economic growth." Growth and Change 43 (1): 56-84.

Diller, Paul A. 2020. “The Political Process of Preemption." University of Richmond Law Review 54:165.

Dodds, H. W. 1924. "City Manager Government in American Municipalities." Journal of Comparative Legislation and International Law 4 (4): 183-192.

Domitrovic, Brian. 2014. Tax Revolt! It's Time to Learn from Past Success. Washington D.C.: CATO Institute.

Douglas, Malinda R., Candida A. Manion, Vanessa D. Hall-Harper, Kristina M. Terronez, Corey A. Love, and Andie Chan. 2015. "Case Studies from Community Coalitions: Advancing Local Tobacco Control Policy in a Preemptive State." American Journal of Preventive Medicine 48 (1): S29-S35.

DuPuis, Nicole, Trevor J. Langan, Christiana K. McFarland, Angelina Panettieri, and Brooks Rainwater. 2018. City Rights in an Era of Preemption: A State-by-State Analysis, 2018 Update. Washington D.C.: National League of Cities.

Einstein, Katherine Levine, and David M. Glick. 2017. "Cities in American Federalism: Evidence on State-Local Government Conflict from a Survey of Mayors." Publius: The Journal of Federalism 47 (4): 599-621.

Ellis, E. G. 2016. “Guess how much that anti-LGBTQ law is costing North Carolina." Wired. 
Flavin, Patrick, and Gregory Shufeldt. 2019. "Explaining State Preemption of Local Laws: Political, Institutional, and Demographic Factors." Publius: The Journal of Federalism.

Florida Advisory Council on Intergovernmental Relations. 1991. 1991 Report on Mandates and Measures Affecting Local Government Fiscal Capacity. Tallahassee: State of Florida.

Foster, Kathryn A. 1997. The Political Economy of Special-Purpose Government. Washington D.C.: Georgetown University Press.

Fowler, Luke, and Stephanie L. Witt. 2019. "State Preemption of Local Authority: Explaining Patterns of State Adoption of Preemption Measures." Publius: The Journal of Federalism 49 (3): 540559.

Frederickson, H. George, and Kevin B. Smith. 2003. The Public Administration Theory Primer. Boulder, CO: Westview Press.

Frug, Gerald E., and David J. Barron. 2008. City Bound: How states Stifle Urban Innovation. Ithica: Cornell University Press.

Gamm, Gerald, and Thad Kousser. 2010. "Broad Bills or Particularistic Policy? Historical Patterns in American State Legislatures." American Political Science Review 104 (1): 151-170.

- 2013. "No Strength in Numbers: The Failure of Big-City Bills in American State Legislatures, 1880-2000." American Political Science Review 107 (4): 663-678.

Garrett, Kristen N., and Joshua M. Jansa. 2015. "Interest Group Influence in Policy Diffusion Networks." State Politics \& Policy Quarterly 15 (3): 387-417.

Gerber, Elizabeth A., Arthur Lupia, Mathew D. McCubbins, and D. Roderick Kiewiet. 2001. Taking the Initiative: How State Government Responds to Direct Democracy. New York: Prentice Hall.

Givel, Michael S., and Stanton A Glantz. 2001. "Tobacco lobby political influence on US state legislatures in the 1990s." Tobacco Control 10:124-134.

Goodman, Christopher B., and Megan E. Hatch. 2020. "State Legislative Ideology and the Preemption of City Ordinances: The Case of Worker Rights Laws." Working paper.

Goodman, Christopher B., and Suzanne M. Leland. 2019. "Do Cities and Counties Attempt to Circumvent Changes in Their Autonomy by Creating Special Districts?" The American Review of Public Administration 49 (2): 203-217.

Goodnow, Frank J. 1895. Municipal Home Rule: A Study in Administration. London: The Columbia University Press.

1900. Politics and Administration: A Study in Government. New York, NY: Macmillan Co.

Gorovitz, Eric, James Mosher, and Mark Pertschuk. 1998. "Preemption or Prevention?: Lessons from Efforts to Control Firearms, Alcohol, and Tobacco." Journal of Public Health Policy 19 (1): 36-50.

Grabar, Henry. 2019. “Legalize It,” July. Accessed December 30, 2019. https:/ / slate.com/busines s/2019/07/oregon-single-family-zoning-apartments-housing.html. 
Guy, Mary E. 2003. "Ties that Bind: The Link Between Public Administration and Political Science." The Journal of Politics 65 (3): 641-655.

Hicks, William D., Carol S. Weissert, Jeffrey Swanson, Jessica Bulman-Pozen, Vladimir Kogan, Lori Riverstone-Newell, Jaclyn Bunch, et al. 2018. "Home Rule Be Damned: Exploring Policy Conflicts between the Statehouse and City Hall." PS: Political Science E Politics 51 (1): 26-38.

Hooghe, Liesbet, and Gary Marks. 2009. “Does Efficiency Shape the Territorial Structure of Government?" Annual Review of Political Science 12 (1): 225-241.

Howell-Moroney, Michael. 2008. "The Tiebout Hypothesis 50 Years Later: Lessons and Lingering Challenges for Metropolitan Governance in the 21st Century." Public Administration Review 68 (1): 97-109.

Kim, Junghack, Bruce D. McDonald III, and Jooho Lee. 2018. "The Nexus of State and Local Capacity in Vertical Policy Diffusion." The American Review of Public Administration 48 (2): 188200.

Linder, Fridolin, Bruce A. Desmarais, Matthew Burgess, and Eugenia Giraudy. 2018. "Text as Policy: Measuring Policy Similarity through Bill Text Reuse." Policy Studies Journal.

Lovrich, Nicholas P., and Meredith A. Newman. 2004. “The Hearing of Local Government Interests in State Legislatures: The Effects of Prior Service in City or County Government." State E Local Government Review 36 (1): 67-77.

MacManus, Susan A. 1991. "“Mad" about mandates: The issue of who should pay for what resurfaces in the 1990s." Publius: The Journal of Federalism 21 (3): 59-75.

Martell, Christine R., and Paul Teske. 2007. "Fiscal Management Implications of the TABOR Bind." Public Administration Review 67 (4): 673-687.

McDonald III, Bruce D. 2015. “Does the Charter Form Improve the Fiscal Health of Counties?" Public Administration Review 75 (4): 609-618.

McDonald III, Bruce D., and Carl J Gabrini. 2014. “Determinants of Charter County Decisions: An Event History Analysis of Florida Counties." Journal of Public Administration Research and Theory 24 (3): 721-739.

McDonald III, Bruce D., Christopher B. Goodman, and Megan E. Hatch. 2020. "Tensions in StateLocal Intergovernmental Response to Emergencies: The Case of COVID-19." Working paper.

Monadari, Fred, and Stanton A Glantz. 1998. "Are tobacco industry campaign contributions influencing state legislative behavior?" American Journal of Public Health 88 (6): 918-923.

Mowery, Paul D., Stephen D. Babb, Robin Hobart, Cindy Tworek, and Allison MacNeil. 2012. “he Impact of State Preemption of Local Smoking Restrictions on Public Health Protections and Changes in Social Norms." Journal of Environmental and Public Health.

Nobles, James, and Roger Brooks. 2000. State Mandates on Local Governments. St. Paul: Office of the Legislative Auditor (MN).

Park, Sungho, Craig S. Maher, and Carol Ebdon. 2018. “Local Property Tax Limits in Nebraska: Within-State Variations in Effects." Public Administration Quarterly 42 (3): 328-371. 
Pertschuk, Mark, Jennifer L. Pomeranz, Julie Ralston Aoki, Michelle A. Larkin, and Marjorie Paloma. 2013. "Assessing the impact of federal and state preemption in public health: A framework for decision makers." Journal of Public Health Management and Practice 19 (3): 213219.

Phillips, Lauren E. 2017. "Impeding Innovation: State Preemption of Progressive Local Regulations." Columbia Law Review 117 (8): 2225-2263.

Pomeranz, Jennifer L., and Mark Pertschuk. 2017. "State preemption: A significant and quiet threat to public health in the United States." American Journal of Public Health 107 (6): 900-902.

. 2019. "Sugar-sweetened beverage taxation in the USA, state preemption of local efforts." Public Health Nutrition 22 (1): 190.

Richardson, Jesse J. 2011. “Dillon's Rule is From Mars, Home Rule is From Venus: Local Government Autonomy and the Rules of Statutory Construction." Publius: The Journal of Federalism 41 (4): 662-685.

Riverstone-Newell, Lori. 2014. Renegade cities, public policy, and the dilemmas of federalism. Boulder, CO: Lynne Rienner Publishers.

- 2017. "The Rise of State Preemption Laws in Response to Local Policy Innovation." Publius: The Journal of Federalism 47 (3): 403-425.

Rosenbaum, Carrie L. 2015. "The Role of Equality Principles in Preemption Analysis of Sub-federal Immigration Laws: The California TRUST Act." Chapman Law Review 18 (2): 481-525.

Ross, Justin. 2018. “Unfunded Mandates and Fiscal Structure: Empirical Evidence from a Synthetic Control Model." Public Administration Review 78 (1): 92-103.

Rutkow, Lainie, Meghan D. McGinty, Sarah Wetter, and Jon S. Vernick. 2019. "Local Public Health Policymakers' Views on State Preemption: Results of a National Survey, 2018." American Journal of Public Health 109 (8): 1107-1110.

Sances, Michael W. Forthcoming. "When Votes Matter: The Limits of Local Government Responsiveness." Urban Affairs Review.

Sanchez, Yvonne Wignett, and Alia Beard Rau. 2016. “Bill Targets Local Government that Violate State Law." Arizona Republic.

Scharff, Erin Adele. 2018. "Hyper Preemption: A Reordering of the State-Local Relationship?" Georgetown Law Journal 106 (4): 1469-1522.

Schneider, Saundra K., William G. Jacoby, and Daniel C. Lewis. 2011. "Public Opinion Toward Intergovernmental Policy Responsibilities." Publius: The Journal of Federalism 41 (1): 1-30.

Siegel, Michael, Julia Carol, Jerie Jordan, Robin Hobart, Susan Schoenmarklin, Fran DuMelle, and Peter Fisher. 1997. "Preemption in Tobacco Control: Review of an Emerging Public Health Problem." The Journal of the American Medical Association 278 (10): 858-863.

Stallmann, Judth I., Steven C. Deller, Lindsay Amiel, and Craig S. Maher. 2012. "Tax and Expenditure Limitations and State Credit Ratings." Public Finance Review 40 (5): 643-669. 
Stallmann, Judth I., Craig S. Maher, Steven C. Deller, and Sungho Park. 2017. "Surveying the Effects of Limitations on Taxes and Expenditures: What Do/Don't We Know?" Journal of Public and Nonprofit Affairs 3 (2): 197-222.

Stephens, G. Ross. 1974. "State Centralization and the Erosion of Local Autonomy." The Journal of Politics 36 (1): 44-76.

Sun, Rui. 2014. "Reevaluating the Effect of Tax and Expenditures Limitations: An Instrumental Variable Approach." Public Finance Review 42 (1): 92-116.

Swanson, Jeffrey, and Charles Barrilleaux. 2018. "State Government Preemption of Local Government Decisions Through the State Courts." Urban Affairs Review.

Swindell, David, James H. Svara, and Carl Stenberg. 2018. "Local Government Options in the Era of State Preemption." Local Government Review, 8-13.

Tiebout, Charles M. 1956. "A Pure Theory of Local Expenditures." Journal of Political Economy 64 (5): 416-424.

Wagner, Spencer, Nestor M. Davidson, Kim Haddow, Alex Jones, Christiana K. McFarland, and Brooks Rainwater. 2019. Restoring City Rights in an Era of Preemption: A Municipal Action Guide. Washington, D.C.: National League of Cities.

White, Leonard D. 1926. Introduction to the Study of Public Administration. New York, NY: Macmillan Co.

Wilkerson, John, David Smith, and Nicholas Stramp. 2015. "Tracing the Flow of Policy Ideas in Legislatures: A Text Reuse Approach." American Journal of Political Science 59 (4): 943-956.

Zimmerman, Joseph F. 2012. State-Local Governmental Interactions. Albany: State University of New York Press. 